\title{
THE HAPPINESS \\ OF INTERPERSONAL RELATIONS
}

In Happiness And Contemporary Society : Conference Proceedings Volume (Lviv, March, 20-21, 2021). Lviv: SPOLOM, 2021. P. 208-210. https://doi.org/10.31108/7.2021.47

ISBN 978-966-919-697-2

\section{ЩАСТЯ \\ МІЖОСОБИСТІСНИХ ВЗАЕМИН}

// Щастя та сучасне суспільство : збірник матеріалів міжнародної наукової конференції (Львів, 20-21 березня 2021 р.). - Львів : СПОЛОМ, 2021. С. 208-210. https://doi.org/10.31108/7.2021.47

ISBN 978-966-919-697-2 


\title{
NAKONECHNA Mariia \\ PhD in Psychology, associate professor \\ Nizhyn Gogol State University (Nizhyn, Ukraine)
}

\section{THE HAPPINESS OF INTERPERSONAL RELATIONS}

Happiness of interpersonal relations stands for mutually developing, mutually enriching, mutually facilitative communication. One of basic themes in world culture is reciprocity in human relations. Various forms interpersonal relations assume different stages in their development, and highly developed forms of interpersonal relations are characterized by intersubjectivity. Intersubjectivity is such form of interaction between people that actualizes aspirations to mutual displays and mutual development of participants' subjectivity. Dialectics of consent and disagreement in intersubjective relations defines a new perspective of both theoretical analysis and empiric researches. Intersubjectivity emerges when group discussion evolves into vivid and active process of finding solutions, and wherein participants listen to each other, paving the way for dialogueness.

Keywords: happiness, intersubjectivity, interpersonal relations, dialogue, interaction, agency.

\author{
НАКОНЕЧНА Марія \\ кандидат психологічних наук, дочент \\ Ніжинський державний університет імені Миколи Гоголя \\ (Ніжин, Україна)
}

\section{ЩАСТЯ МІЖОСОБИСТІСНИХ ВЗАЕМИН}

Щастя міжособистісних взаємин - це взаєморозвивальне, взаємозбагачувальне, взаємофасилітуюче спілкування. Одна із наріжних тем світової культури - це проблема взаємності. Різні міжособистісні стосунки припускають різні рівні розвитку, при цьому високорозвиненим формам міжособистісних взаємин притаманна властивість інтерсуб'єктності, на якій хотілося б зупинитися детальніше.

Інтерсуб'єктність - це взаємодія між людьми, яка актуалізує прагнення до взаємних виявів і взаємного розвитку суб'єктності учасників. Входячи в інтерсуб' єктні взаємини, учасники прагнуть, по-перше, досягти цілей діяльності, а по-друге, сприяти взаємному розвитку станів суб'єктності - щоб всі учасники взаємодії розвивали власну суб'єктність.

Є. Матусов пропонує визначення інтерсуб'єктності як такої, яка триває, поки $є$ спільна діяльність; при цьому важливими є аспекти згоди та незгоди. Щоб мати повнішу картину того, чим є інтерсуб'єктність, слід аналізувати не тільки те, як люди згоджуються та діляться чимось, але і як вони не згоджуються, але в спонтанно організованій активності знаходять точки дотику $\mathrm{i}$ розвивають відносини інтерсуб’єктності. На думку Є. Матусова, існує два основні підходи до 
інтерсуб'єктності: 3 позицій епістемологічної теорії Ж. Піаже та 3 позицій культурно-історичної теорії Л.С. Виготського. Якщо Ж. Піаже та його послідовники зосереджувалися на тому, як вирішити когнітивний чи моральний конфлікт, то Л.С. Виготський та його школа предметом уваги зробили інтерсуб'єктні відносини, які передують формуванню інтрапсихологічних функцій. $€$. Матусов завершує статтю посиланням на Ромметвейта, згідно 3 яким інтерсуб'єктність не досягається, а приймається як належне в світі, яким всі взаємно діляться [2, с. 41]. Такий підхід до інтерсуб'єктності інтегрує досягнення культурно-історичної теорії та діяльнісного підходу в психології. $Є$. Матусов пропонує макро- та мікро-аналіз інтерсуб'єктної активності, причому змістом аналізу можуть бути різні ситуації інтерсуб'єктності, зокрема обставини дитячої гри. Важливо, зазначає автор, вивчати не тільки спеціально організовані, але й спонтанні вияви інтерсуб'єктної активності. Діалектика згоди та незгоди у відносинах інтерсуб'єктності задає новий вектор теоретичного аналізу та можливих емпіричних розвідок.

Г.А. Цукерман зазначає: «...Учіннєва діяльність - це експериментальний метод вивчення дитячого розвитку засобами освіти» [1, с. 52]. Розвивальне навчання за системою Д.Б. Ельконіна - В.В. Давидова створює особливі ситуації інтерсуб'єктності у взаємодії вчителя та учнів та учнів між собою. Це такі ситуації, де враховується ініціатива та творчість, де вибудовується зона найближчого розвитку та стає актуальною нова система відносин інтерсуб'єктності, через яку створюються та народжуються нові міжфункціональні психологічні системи, забезпечуючи особистісний розвиток учасників. I тоді вірним $\epsilon$ те, що формувальний експеримент як спосіб пізнання інтерсуб'єктної взаємодії можливий в першу чергу в освітній системі, що особливо правдиве для юнацького віку, коли важливим $\epsilon$ опанування учбово-професійною діяльністю. Розуміння спільної діяльності як принципово інтерсуб'єктної припускає, що в процесі учіння суб'єкти оволодівають навчальними змістами через систему дій та відносин, що складаються між учасниками освітнього процесу. Інтерсуб'єктність виникає тоді, коли групове обговорення стає жвавим, ініціативним процесом пошуку групового рішення, i там, де учасники дослухаються один до одного, проторюючи шлях діалогічності. Отже, інтерсуб'єктна взаємодія - це важлива складова спільної учіннєвої діяльності, в якій підкреслюються моменти спільності та взаємності. Знову ж таки, можна говорити про макро- і мікроаналіз, тепер уже під час уроків та занять у вищих навчальних закладах. Там і тоді, коли під час групової дискусії народжується розуміння істини, виникають відносини інтерсуб'єктності як вільного, діалогічного врахування і саморуху (саморозвитку) суб'єктностей учасників.

Міркуючи над загальною схемою інтерсуб'єктної взаємодії, приходимо до таких узагальнень.

У двох особистостей виникають потреби. Вони, так само як і мотиви та цілі, можуть бути однаковими у різних людей, або різними. Потреби передбачають очікування щодо продукту діяльності. Потреби опредметнюються в мотивах. 3 мотивів виникають цілі. Цілі породжують дії. Суб'єкти діяльності S1 та S2 можуть зіткнутися з тим, що досягти мети можливо, лише об'єднавши зусилля та ресурси. Виникає перехрещування дій. Дія 1 означає дію, необхідну для здійснення 
діяльності та досягнення мети, а дія 2 - це дія, спрямована на пошук партнерства, дія, де особистість 1 слідкує, щоб особистість 2 реалізувала свою суб'єктність у взаємодії. Виникає спілкування, прив'язане до цілей дій, спілкування 3 приводу спільної діяльності.

Інтерсуб'єктна взаємодія не дорівнює бажанню, а виникає з необхідності задоволення потреб кожного. Взаємовідносини не дорівнюють взаємодії. Можуть бути взаємовідносини без взаємодії, - наприклад, спілкування, не пов'язане 3 виконуваною діяльністю.

Умовою виникнення «перехрещування» дій $\epsilon$ сильна мотивація, яка у кожної особистості фруструється на певному етапі і вона не може сама завершити дію і отримати продукт. Коли виникає необхідність перехрещування дій, то особистість 1 очікує, що особистість 2 є компетентною, досвідченою, добросовісною, чесною та надійною. Це особистісний бік інтерсуб'єктної взаємодії. Діяльнісний бік інтерсуб'єктної взаємодії пов'язаний з тим, що обидві особистості виконують, як мінімум, дві дії: 1) дію як частину виконуваної загальної діяльності, спрямовану на досягнення конкретної діяльнісної мети; 2) дію із врахування та забезпечення реалізації суб'єктної позиції іншого учасника.

Таким чином, інтерсуб'єктна взаємодія виникає із необхідністю в ситуації, де одноосібне досягнення мети $є$ неможливим, і призводить до формування спільного мотиву та до створення спільного продукту діяльності.

Інтерсуб'єктна взаємодія в площині суб'єктивного буття особистості дає відчуття щастя, реалізації, наповненості, потоку, радості. Тому важливо досліджувати різні психологічні аспекти інтерсуб'єктної взаємодії, яка розкриває повноту щасливих міжособистісних взаємин.

\section{ЛIТЕРАТУРА}

1. Цукерман Г.А. Совместное учебное действие: решенные и нерешенные вопросы. Психологическая наука и образование. 2020. Том 25. № 4. С. 51-59. DOI: https://doi.org/10.17759/pse.2020250405

2. Matusov E. Intersubjectivity Without Agreement. Mind, Culture, and Activity. 1996. 3(1). Pp. 25-45. doi: 10.1207/s15327884mca0301_4 